\title{
TREE RING STUDIES IN THE TROPICS AND SUBTROPICS
}

\author{
Dieter Anhuf and Gerhard H. Schleser
}

According to the Intergovernmental Panel on Climate Change the global surface temperature has continuously risen since 1861 . Increasing temperatures combined with changing precipitation patterns are strong indications for a more active and more intense hydrological cycle in the coming decades. In this respect, it is undisputed that the tropical regions are important for the global climate system. The reaction of tropical forests to enhanced atmospheric $\mathrm{CO}_{2}$ concentrations plays a pivotal role for the land carbon and the land water cycle. Currently our understanding of the physiological reactions such as growth response of tropical trees to rising atmospheric $\mathrm{CO}_{2}$ concentration, partly related to water-use-efficiency (WUE) and climate change is still rather poor and controversially discussed (Frank et al. 2015). Modifications in their carbon uptake and transpiration rate have inevitably global consequences. It is still unclear if tropical trees assimilate more $\mathrm{CO}_{2}$ with constant or slightly reduced water losses in a $\mathrm{CO}_{2}$ richer world or if the carbon gain remains almost unchanged with reduced transpiration.

Tree-rings are well suited for environmental investigations with much potential for verifications of their well-being. Tree rings are mostly annually resolved, contain environmental information, are easily sampled and as such valuable archives. Growth limiting factors control the development of trees allowing the derivation of transfer functions that relate tree growth to tree physiological quantities as well as climatic parameters (COOK and KAIRIUKSTIS 1992; FritTs 1976).

Up to now hemispheric investigations using tree rings are mainly based on data sets of mid and high latitude sites or Nordic tree-line sites. Investigations based on trees of tropical or subtropical regions are comparatively rare. This has several causes. One reason is the difficulty to identify tree-rings or growth increments of annual resolution. Consequently, it is often demanding to construct reliable data sets, i.e. chronologies of annual time resolution, for extracting climatic signals and/or tree physiological parameters. Therefore, tropical or subtropical trees have only just recently come into focus of environmentalists and climatologists. Subsequently tree-ring widths chro- nologies of tropical tree ensembles are anything but numerous and chronologies, e.g. regarding stable isotopes are almost non-existent.

Up to now, not many tree-ring chronologies from the tropics and subtropics exist, although investigations in these areas have recently increased (RozendaAl and Zuidema 2011). For such investigations chronologies of high time resolution are needed. They are, however, rare because for many of the tree species tree-rings are difficult to classify as annual rings (BIONDI et al. 1999; LisI et al. 2008). Therefore, it is often complicated to use tropical and subtropical trees for highly resolved ecophysiological or climatological studies. On the other hand, SCHÖNGART et al. (2007) demonstrated that the application of classical dendrochronology can provide climate information using tree rings from topical floodplain trees.

Growth limiting factors which in many cases show up in tree-rings as particular proxies do vary, depending on the area in which the trees develop. Precipitation is certainly the dominant growth limiting factor for tropical areas. Within the State of São Paulo, a subtropical area, temperature may vary by as much as $10^{\circ} \mathrm{C}$, thus, indicating that even temperature must be considered in some tropical areas (SILVA et al. 2009). An important additional factor for tree growth is presumably the steadily increasing atmospheric $\mathrm{CO}_{2}$ concentration

The examination and description of naturally growing trees in their habitat and the patterns they develop is an important topic of dendrochronological research within the tropics and in many subtropical regions. The unusually large diversity of tropical but partly also subtropical tree species requires numerous investigations (e. g. BuCKLEY et al. 1995 and JALIL et al. 1998). Delimitation of tree-ring boundaries, i.e. the determination of interannual increments, is challenging even for a number of tree species from subtropical regions (Lisi et al. 2008). In this respect isotope analyses, may ease the problem of determining tree-ring boundaries of trees having problematic or indistinct tree rings (Pons and Helle 2011). This is based on the fact, that in cases of ambiguous tree-rings isotopes of the corresponding wood sections, subdivided into 
thin sections of sometimes down to roughly $20 \mu \mathrm{m}$ allow the determination of boundaries (e.g. VERHEYDEN et al. 2004; SCHLesER et al. 2015). Stable carbon and oxygen isotopes of thin section investigations can also provide short term environmental signals since they may resolve intra-annual events (PoussART et al. 2004; Helle and Schleser 2004). Based on the carbon and oxygen isotopes of intra-annual tree-ring series e.g. VERHEYDEN et al (2004) were able to trace the El Niño event of 1997, whereas neither the tree ring width of 1997 nor the tree-ring width of 1998 registered this event.

Besides the usage of tree-ring widths, tree-ring density (SCHWEINGRUBER et al. 1978), vessel area and stable isotopes, especially $\delta^{13} \mathrm{C}$ und $\delta^{18} \mathrm{O}$ have been established as valuable proxies for ecophysiological studies (GAGEN et al. 2011). Notably stable isotopes have lately shown a very promising potential for the reconstruction of tree behaviour in relation to past environmental variations (e.g. VOLLAND et al 2016).

The currently available studies on tropical wood samples indicate that isotope signals can either be used to detect tree-ring boundaries and/or derive highly resolved environmental and tree physiological properties. Thus, isotopes may serve two purposes: on the one hand, they allow a proper determination of treerings using thin section isotope samples by applying laser microdissection techniques (if necessary) and on the other hand they allow statements about environmental and/or climate changes within their habitat.

The reaction of tropical forests to the rising atmospheric $\mathrm{CO}_{2}$ concentration plays a pivotal role for the land carbon and water cycles (HuNTINGFORD et al. 2011). Stomata are the interface at which plants optimize their performance by maximizing carbon gain and minimizing water loss. Their responsiveness is a key in controlling the two cycles. Tropical forests represent a huge carbon sink and generate nearly half of the global precipitation amount (RAUPACH and Canadell 2010). Up to now our understanding of the physiological reactions of tropical trees to rising atmospheric $\mathrm{CO}_{2}$ concentrations and climate change is very poor and is discussed controversially (CERNUSAK et al. 2011). It is unclear if tropical trees assimilate more $\mathrm{CO}_{2}$ with constant water losses or the carbon gain remains unchanged with reduced transpiration. Theoretically this could imply that the land water cycle is slowing down and carbon sequestration is rising (Holtum and Winter 2010). The ratio between assimilated $\mathrm{CO}_{2}$ and transpired $\mathrm{H}_{2} \mathrm{O}$ is the main determinant for the cycling of water on land and, therefore, the precipitation above continental areas (SHEIL and MurdiYARSO 2009).
Due to the rising atmospheric $\mathrm{CO}_{2}$ concentration many ecophysiological studies concentrate on the assumed $\mathrm{CO}_{2}$-fertilization effect especially with respect to the water and carbon balance of trees. Water use efficiency (WUE) is a suitable quantity to describe this process. In a broader sense the WUE reflects the carbon and water economics of a tree. WUE is normally expressed as intrinsic water use efficiency (iWUE) which is proportional to the existing and known leaf external to leaf internal $\mathrm{CO}_{2}$ concentration difference $\left(\mathrm{C}_{\mathrm{a}}-\mathrm{C}_{\mathrm{i}}\right)$. Contrary to WUE which additionally considers the actual water consumption, iWUE can be regarded as a key measure of the water costs to maintain a fixed rate of carbon assimilation. Knowledge of $\mathrm{C}_{\mathrm{i}}$ from stable carbon isotopes of tree-rings and the time series of $\mathrm{C}_{\mathrm{a}}$ (e.g. from ice cores or meteorological measurements), are the decisive elements to develop water use efficiency scenarios. While some studies for temperate regions have lately been published showing water use efficiency (iWUE) and transpiration e.g. for European forests (FrANK et al. 2015), similar studies for tropical regions to predict sequences of transpiration events are still missing. In view of the importance of tropical forests for the global climate system this should certainly be a venture for the future. Annually resolved long-term carbon isotope tree-ring measurements across a tropical forest network, e.g. the Amazon region, could be used to reconstruct the physiologically driven response of intercellular $\mathrm{CO}_{2}$ due to the increasing atmospheric $\mathrm{CO}_{2}$ concentration.

During the last years improvements in sample preparation and advances in mass spectrometry have paved the way for generating isotope ratios from wood samples much easier and faster. Although meteorological quantities cannot directly be related to isotope ratios of tree-rings they are well suited as proxies for environmental studies. Depending on the sites in which trees grow they may provide surrogates for temperature, precipitation or other environmental parameters. At this point it should be stressed that isotope ratios do not, however, replace tree-ring widths and vessel area information. Isotope ratios and anatomical features (tree-ring-widths, vessel areas) can complement one another to gain more information about the environmental conditions under which trees grow (SIDAROVA et al. 2011; McCaroll et al. 2011).

The current volume of "Erdkunde" is dedicated to modern research in the field of dendrochronology in the tropics and subtropics. It should, however, be stressed that such a topic is too broad to be treated in a comprehensive way in one volume. Five different papers have been selected. The first treatise (FICHTLER 2017) is a review on the use of tropical tree species in 
dendroclimatology, followed by an article that is concentrating on African Baobabs from Botswana (SLOTTA et al. 2017). Missing and false tree rings, often a problem with tropical tree species, are the topic of this article. It demonstrates that these problems can possibly be circumvented due to strong relationships between tree-ring width and annual precipitation amount, allowing in the actual case the development of a preliminary chronology. Subsequently, significant correlations of the carbon discrimination $\left(\Delta^{13} \mathrm{C}\right)$ and the oxygen isotopes of tree rings with climate data are reported. The third paper (LocosselLI et al. 2017), is somewhat more specific and deals with the age trends and radial growth rates of three Hymenaea species inhabiting four of the six biomes found in Brazil. The article of PITSCH et al. (2017) addresses the suitability of Cariniana estrellensis for dendrochronological and dendroecological investigations. The last paper (BEN et al. 2017) presents for the first time a study on growth periodicity and stable carbon isotope ratios based on tree ring cellulose of a tree species with $\mathrm{C}_{4}$ photosynthesis. These results are compared with the corresponding data of a $\mathrm{C}_{3}$ tree species from the same habitat in Hawaii.

\section{References}

Ben, T; Hart, P. J. and Helle, G. (2017): Towards establishing a new environmental archive - Annual growth periodicity, stable carbon isotope variability and reconstruction potential of 'Akoko (Euphorbia olowaluana), a native Hawaiian tree with $\mathrm{C}_{4}$ photosynthetic pathway. In: Erdkunde 71 (1), this volume, 77-92. https://doi. org/10.3112/erdkunde.2017.01.05

Biondi, F.; Estrada, I. G.; Burton, A.; Metcalfe, S. E.; Cayan, D. R. and Berger, W. H. (1999): A 400-year treering chronology from the North American tropics. In: American Meteorological Society (ed.): Proceedings of the 10th Symposium on Global Change Studies, Boston, 161-162.

Buckley, B. M.; Barbetti, M.; Watanasak, M.; D `Arrigo, R.; Boonchirdchoo, S. and Sarutanon, S. (1995): Dendrochronological investigations in Thailand. In: IAWA Journal 16, 393-409. https://doi.org/10.1163/2294193290001429

Cernusak, L. W.; Martínez, C.; Correa, E.; Aranda, J.; GarCIA, M. and Jaramillo, C. (2011): Responses of legume versus nonlegume tropical tree seedlings to elevated $\mathrm{CO}_{2}$ Concentration. In: Plant Physiology 157, 372-385. https://doi.org/10.1104/pp.111.182436

Cook, E. R. and Kairiukstis, L. A. (eds.) (1992): Methods of dendrochronology - Applications in the environmental sciences. Dordrecht.
Fichtler, E. (2017): Dendroclimatology using tropical broadleaved tree species - a review. In: Erdkunde 71 (1), this volume, 5-22. https://doi.org/10.3112/erdkunde.2017.01.01

FrITTS, H. C. (1976): Tree rings and climate. London.

Frank, D. C.; Poulter, B.; Saurer, M.; Esper, J.; Huntingford, C.; Helle, G.; Treydte, K.; Zimmermann, N. E.; Schleser, G. H.; Ahiström, A.; Ciais, P.; Friedlingstein, P.; Levis, S.; Lomas, M.; Sitch, S.; Viovy, N.; Andreu-Hayles, L.; Bednarz, Z.; Berninger, F; Boettger, T.; D'Alessandro, C. M.; Daux, V.; Filot, M.; Grabner, M.; Gutierrez, E.; Haupt, M.; Hilasvuori, E.; Jungner, H.; Kalela-Brundin, M.; Krapiec, M.; Leuenberger, M.; LoAder, N. J.; Marah, H.; Masson-Delmotte, V.; Pazdur, A.; PawelczyK, S.; Pierre, M.; Planelds, O.; Pukiene, R.; Reynolds-Henne, C. E.; Rinne, K. T.; Saracino, A.; Sonninen, E.; StieveNard, M.; Switsur, V. R.; SzczepaneK, M.; SzychowskaKrapiec, E.; Todaro, L.; Waterhouse J. S. and Weigl, M. (2015): Water-use efficiency and transpiration across European forests during the Anthropocene. In: Nature Climate Change 5, 1-6. https://doi.org/10.1038/nclimate2614

Holtum, J. and Winter, K. (2010): Elevated [CO $\left.{ }_{2}\right]$ and forest vegetation: more a water issue than a carbon issue? In: Functional Plant Biology 37, 694-702. https://doi. org/10.1071/FP10001

Gagen, M.; McCarroll, D.; Loader, N. and Robertson, I. (2011): Stable isotops in dendroclimatology: moving beyond 'potential'. In: Hughes, M. K.; Swetnam, T. W. and Diaz, H. F. (eds.): Dentroclimatology. Progresses and prospects. Dordrecht.

Helle, G. and Schleser, G. H. (2004): Beyond $\mathrm{CO}_{2}$-fixation by Rubisco - an interpretation of ${ }^{13} \mathrm{C} /{ }^{12} \mathrm{C}$ variations in tree rings from novel intra-seasonal studies on broad-leaf trees. In: Plant, Cell and Environment 27, 367-380. https:/ / doi. org/10.1111/j.0016-8025.2003.01159.x

Huntingford, C.; Cox, P.; Mercado, L. M.; Sitch, S.; BellouIN, N. and Boucher, O. (2011): Highly contrasting effects of different climate forcing agents on terrestrial ecosystem services. In: Philosophical Transactions of the Royal Society A 369, 2026-2037. https://doi.org/10.1098/ rsta.2010.0314

Jalit, N. R. A; ITOH, T.; SAhri, M. H. and Jusoh, M. Z. (1998): Periodicity of xylem growth of rubberwood (Hevea brasiliensis) grown in Malaysia. In: Holzforschung 52, 567-572. https://doi.org/10.1515/hfsg.1998.52.6.567

Lisi, C. S.; Fo, M. T.; Botosso, P. C.; Roig, F. A.; Maria, V. R. B.; Ferreira-Fedele, L. and Voigt, A. R. A. (2008): Treering formation, radial increment periodicity, and phenology of tree species from a seasonal semi-deciduous forest in southeast Brazil. In: IAWA Journal, 29 (2), 189-207. https://doi.org/10.1163/22941932-90000179

Locosselli, G. M.; Krottenthaler, S.; Pitsch, P.; Anhuf, D. and Ceccantini, G. (2017): Age and growth rate of congeneric tree species (Hymenaea spp. - Leguminosae) 
inhabiting different tropical biomes. In: Erdkunde 71 (1), this volume, 45-57. https://doi.org/10.3112/erdkunde.2017.01.03

McCarroll, D.; Tuovinen, M. C.; Campbell, R.; Gagan, M.; Grudd, H.; Jalkanen, R.; Loader, N. J. and Robertson, I. (2011): A critical evaluation of multi-proxy dendroclimatology in northern Finland. In: Journal of Quaternary Science 26 (1), 7-14. https:/ / doi.org/10.1002/jqs.1408

Pitsch, P.; Krottenthaler, S.; Locosselli, G. M.; Altman, J.; Neuwirth, B. and Ceccantini, G. (2017): On the suitability of Cariniana estrellensis (Raddi) Kuntze for dendroclimatic studies: the problem of chronology building and trends in lifetime growth trajectories. In: Erdkunde 71 (1), this volume, 59-75. https://doi.org/10.3112/erdkunde.2017.01.04

Pons, T. L. and Helle, G. (2011): Identification of anatomically non-distinct annual rings in tropical trees using stable isotopes. In: Trees 25 (1), 83-93. https:/ / doi.org/10.1007/ s00468-010-0527-5

Poussart, P. F.; Evans, M. N. and Schrag, D. P. (2004): Resolving seasonality in tropical trees: multidecade, highresolution oxygen and carbon isotope records from Indonesia and Thailand. In: Earth and Planetary Science Letters 218, 301-316. https://doi.org/10.1016/S0012821X(03)00638-1

Raupach, M. and Canadella, J. (2010): Carbon and the Anthropocene. In: Current Opinion in Environmental Sustainability 4, 210-218. https://doi.org/10.1016/j.cosust.2010.04.003

RozendaAl, D. and Zuidema, P. (2011): Dendroecology in the tropics: a review. In: Trees 25 (1), 3-16. https://doi. org/10.1007/s00468-010-0480-3

Schleser, G. H.; Anhuf, D.; Helle, G. and Vos, H. (2015): A remarkable relationship of the carbon isotopic composition of wood and cellulose in tree-rings of the tropical species Cariniana micrantha (Duke) from Brazil. In: Chemical Geology 401, 59-66. https:/ / doi.org/10.1016/j.chemgeo.2015.02.014

Schöngart, J.; Wittmann, F.; Worbes, M.; Piedade, M. T. F; Krambeck, H-J. and Junk, W. (2007): Management criteria for Ficus insipida Willd. (Moraceae) in Amazonian white-water floodplain forests defined by tree-ring analysis. In: Annals of Forest Science 64 (6), 657-664. https:/ / doi.org/10.1051/ forest:2007044

Schweingruber, F. H.; FritTs, H. C.; BrÄKer, O. U.; Drew, L. G. and SCHÄr, E. (1978): The X-ray technique as applied to dendroclimatology. In: Tree-Ring Bulletin 38, 61-91.

SheIL, D. and Murdiyarso, D. (2009): How forests attract rain: an examination of a new hypothesis. In: Bioscience 59, 341-347. https://doi.org/10.1525/bio.2009.59.4.12

Sidorova, O. V.; Saurer, M.; Myglan, V. S.; Eichler, A.; Schwikowski, M.; Kirdyanov, A. V.; Bryukhanova, M. V.; Gerasimova,O. V.; Kalugin, I. A.; Daryin, A. V. and Siegwolf, R. T. W. (2012): A multi-proxy approach for revealing recent climatic changes in the Russian $\mathrm{Al}$ tai. In: Climate Dynamics 38 (1), 175-188. https://doi. org/10.1007/s00382-010-0989-6

Silva, L. C. R.; Anand, M.; Oliveira, J. M. and Pillar, V. D. (2009): Past century changes in Araucaria angustifolia (Bertol.) Kuntze water use efficiency and growth in forest and grassland ecosystems of southern Brazil: implications for forest expansion. In: Global Change Biology 15 (10), $2387-$ 2396. https://doi.org/10.1111/j.1365-2486.2009.01859.x

Slotta, F.; Helle, G.; Heussner, K.-U.; Shemang, E. and Riedel, F. (2017): Baobabs on Kubu Island, Botswana A dendrochronological multi-parameter study using ring width and stable isotopes $\left(\delta^{13} \mathrm{C}, \delta^{18} \mathrm{O}\right)$. In: Erdkunde 71 (1), this volume, 23-43. https://doi.org/10.3112/erdkunde.2017.01.02

Verheyden, A.; Helle, G.; Schleser, G. H.; Dehairs, F.; Beeckman, H. and Koedam, N. (2004): Annual cyclicity in high-resolution stable carbon and oxygen isotope ratios in the wood of the mangrove tree Rhizophora mucronata. In: Plant, Cell and Environment 27 (12), 1525-1536. https:/ / doi.org/10.1111/j.1365-3040.2004.01258.x

Volland F.; Pucha, D. and BräunING, A. (2016): Hydro-climatic variability in southern Ecuador reflected by tree-ring oxygen isotopes. In: Erdkunde 70 (1), 69-82. https:/ / doi. org/10.3112/erdkunde.2016.01.05

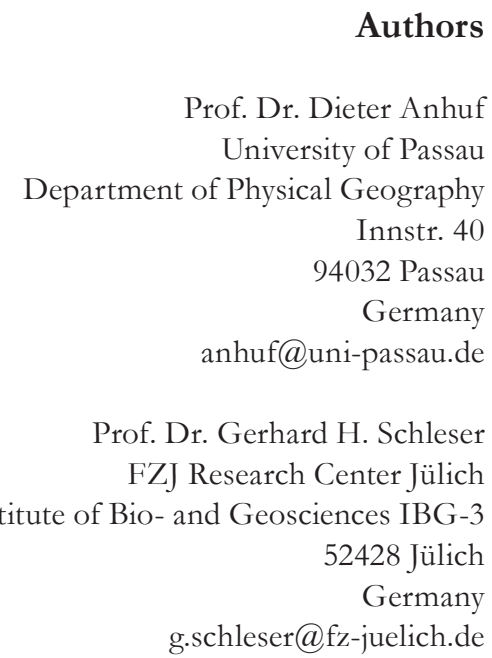

Authors

Prof. Dr. Dieter Anhuf of Passau Innstr. 40 4032 Passau ermany rof. Dr. Gerhard H. Schleser FZJ Research Center Jülich Institute of Bio- and Geosciences IBG-3 52428 Jülich g.schleser@fz-juelich.de 